\title{
THE GOVERNMENT MEDICAL SERVICE IN MALAWI: AN ADMINISTRATIVE HISTORY, 1891-1974
}

\author{
by
}

\section{COLIN BAKER*}

\section{SUMMARY}

MANY departments of government in present-day Africa are the outcome of developments which reach back well into pre-independence times. In Malawi the development of the Ministry of Health can be traced to the very beginning of colonial rule, and as a distinct functional unit of central government it is almost as old as the Government itself.

It is the purpose of this article to trace this development from the founding of the Protectorate in 1891 to the present day, by examining the changes in staffing, financing and policy. Although not dealt with in this administrative history, the part played by the various Missions has been considerable. Their doctors, nurses and hospitals have complemented those of the Government and have added much to the medical facilities. ${ }^{1}$

The country was first named British Central Africa (1891-1907) and then Nyasaland (1907-1964) and, finally, as an independent state, Malawi. A small country of some 36,000 square miles, it has an economy overwhelmingly agrarian, and a population - which grew from about three-quarters of a million in 1891 to four and a half millions in 1974 -overwhelmingly rural. Lacking mineral resources and industrial development, and relying heavily on the exportation of a few crops, it has never been wealthy. It is against this background that the history of the government medical service must be viewed.

The first government doctor in British Central Africa, Sorabji Boyce, was appointed, only two weeks after the Protectorate had been declared on 14 May 1891, as medical

*Colin Baker, The Polytechnic of Wales, Pontypridd, Mid Glamorgan CF37 1DL.

1 The Missions' contribution is difficult to quantify, since most accounts are in general terms. The Scottish Mission has employed doctors since 1876; early in the 1900s one doctor personally treated 1,500 cases a month; in 1911 a $£ 5,000$ hospital was opened; in 1914 their ten dispensaries dealt with 27,000 cases. (W. P. Livingstone, Laws of Livingstonia, London, Hodder \& Stoughton [1921], pp. 310 , 341, 349). The Universities' Mission has employed doctors since 1899 (M. McCulloch, $A$ time to remember, London, 1959, p. 73); in 1908 they dealt with 600 in-patients and 37,000 out-patients (A. Colville, 1,000 Miles in a Machila, London, Walter Scott Publishing Co., 1911, p. 287); in 1939 there were two doctors and twenty nurses (A. G. Blood, The history of the U.M.C.A., vol. 3, London, Universities Mission to Central Africa, 1962, pp. 142-144). In 1970 the 48 Mission hospitals and 100 dispensaries recorded 2,000,000 out-patient attendances, 1,000,000 in-patient days and 30,000 deliveries (Malawi: an official handbook, Blantyre, 1970, p. 79). 


\section{The government medical service in Malawi, 1891-1974}

officer to the Commissioner, Harry Johnston, his staff and the police force. ${ }^{2}$ Although the distinction between civil, police and military work was not clearly made at that time, Johnston looked upon his doctors as members of a civil medical service, and not merely military medical officers. There were, indeed, naval doctors on the lake and river gunboats ${ }^{3}$ but they confined themselves to caring for naval personnel and were not otherwise part of a government medical service.

Dr. Boyce was killed in December 1891,4 and already another government doctor, Alan Watson, had been employed. Unlike Boyce, whose duties were entirely medical, Watson was engaged originally as an administrator. During 1892, however, his duties became more medical, since Johnston then reported, "we have . . our medical service under Dr. Watson". ${ }^{5}$ Even so, he was formally an assistant collector, and seems to have preferred administration to medical practice; "... it is not [my] position as Magistrate to doctor sick people". ${ }^{6} \mathrm{He}$ left in 1894 to join the administration of North Eastern Rhodesia.?

In March 1895, Wordsworth Poole, the son and grandson of medical men, arrived as medical officer. ${ }^{8}$ Like Watson, he was head and sole member of the medical "department" but, unlike Watson, he held no administrative post.

At the time of Watson's departure, Johnston asked the Foreign Office to appoint Percy Rendall as principal medical officer, and he arrived in April 1895. Ever anxious to engage men with a plurality of specializations, Johnston realized that in Rendall he was securing "a very distinguished zoologist besides . . . an excellent doctor".? Rendall stayed less than a year but his successor lasted an even shorter time. Dr. Churchill came to Central Africa "touring ... or perhaps as a speculation"10 and was appointed temporarily to take Rendall's place. He arrived on a Friday and died on the following Sunday. ${ }^{11}$

Poole became principal medical officer ${ }^{12}$ and was joined in 1896 by Dr. Herbert Hearsey ${ }^{18}$ and Dr. Kerr Cross. ${ }^{14}$ There is also the possibility that a Dr. Smith was in the service. ${ }^{15}$ Little is known of the naval doctors, but at various times between 1893 and 1896 there were at least nine. ${ }^{16}$

In June 1897, Poole left the country and was replaced as principal medical officer by $\mathbf{G}$. Douglas Gray who, after a few months as an assistant collector, had become

M. Gelfand, Lakeside pioneers, Oxford, Blackwells, 1964, p. 269.

' 'Lake Nyasa in 1893', Nyasaland J., January 1962, 15: no. 1, 55-58; Edward Alston's diary, 4 February 1895; British Central Africa Gazette; M. Gelfand, 'Doctor on Lake Nyasa', Cent. Afr. J. Med., May 1961, 7: no. 5, supplement, 22.

- H. H. Johnston, British Central Africa, London, Methuen, 1897, p. 104.

Johnston to Weatherley, 22 October 1892.

- I. M. Graham, 'A quarrel at Lake Mweru', Northern Rhodesia J., 1961, 4: no. 6, 555.

? Ibid., p. 552.

- Gelfand, op. cit., note 3 above, p. 17.

- F.O. 2/67, p. 289.

10 Gelfand, op. cit., note 3 above, p. 55.

11 Edward Alston's Diary, 2 April 1896; British Central Africa Gazette, 15 April 1896.

12 Gelfand, op. cit., note 3 above, p. 17.

18 British Central Africa Gazette, 1 October 1896.

14 Ibid., 15 June 1897.

15 Ibid., 1 July 1896. The reference here is to Warrington and Middleton taking over Mpezeni's Station from Dr. Smith and Mr. Frazer.

10 Doctors Harper, Mckay, Dowson, Price, Grant, Bradley, Willis, Ferguson and Staleworth. 


\section{Colin Baker}

medical officer just before Poole's departure. ${ }^{17}$ Similarly, Highett Westbury, who had also been appointed assistant collector, transferred to the medical service in 1897, but very soon died of apoplexy. ${ }^{18}$

In 1897 the medical department consisted of a principal medical officer and two medical officers, ${ }^{19}$ but the numbers soon began to increase, and by the end of 1901 another six doctors and seven female nurses had been appointed. ${ }^{20}$ The position, then, at the end of the Protectorate's first decade was that of those medical officers who had been engaged in government service, four were dead, ${ }^{21}$ nine remained, ${ }^{22}$ and the rest had left. Hospitals had been built at Zomba, Fort Johnston and Karonga, and the public hospital at Blantyre had been taken over by the administration. ${ }^{23}$ The cost of these medical services-almost exclusively curative-rose from $£ 250$ in 1891 to $£ 5,000$ in 1900; the proportion of total government expenditure devoted to them varied between two per cent and four per cent and the per capita expenditure remained well below one penny. ${ }^{24}$

By 1900 the medical department was already well established as a distinct and specialized functional unit of government. Organizationally, there was a principal medical officer in charge of eight medical officers and seven nursing sisters, and professionally all were specialist civil officers; Watson, Gray and Westbury had been district administrators as well as medical men, Rendall had been more entomologist than medical practitioner, and one-third of all those so far engaged had been naval officers as well as doctors. The average length of the doctors' government service in Central Africa was only two years, but one had practised medicine there since $1886,{ }^{25}$ and another had previously served in India; ${ }^{26}$ of the remainder, at least one had qualified only a few months before he arrived in the country. ${ }^{27}$

During the next decade the size of the department remained the same but the annual recurrent expenditure rose from $£ 5,000$ to $£ 9,000$, and consequently the proportion of recurrent expenditure devoted to personal emoluments fell annually, from ninety per cent at the turn of the century to sixty-two per cent in 1910. The proportion of total government recurrent expenditure devoted to the medical department reached the seven per cent to eight per cent level which was to become the "normal" level for several decades. Capital expenditure on medical works probably did not exceed a total of $£ 2,000$ during this decade, and was spent mainly on repairs to hospitals, on a lunatic asylum, and on new staff houses. ${ }^{28}$

${ }^{17}$ Gelfand, op. cit., note 2 above, p. 272; British Central Africa Gazette, 29 November 1897.

18 Ibid., 29 November 1897, 5 February 1898.

10 Johnston, op. cit., note 4 above, p. 152.

${ }^{20}$ British Central Africa Gazette, 26 February 1898, 30 April 1898, 21 May 1898, 30 July 1898, 31 March 1900, 30 November 1900, 31 January 1901, 28 February 1901.

21 Boyce, Westbury, Churchill, Mckay.

22 Hearsey, Cross, Gray, Hardy, Higgins, Morrough, Barclay, Wykesmith and Old.

22 Gelfand, op. cit., note 2 above, p. 265.

24 Details of expenditure and figures of staff numbers throughout this article are taken from the Annual Estimates.

${ }^{26}$ J. W. Jack, Daybreak in Livingstonia, London, Oliphant, Anderson \& Ferrier, 1901, p. 171. This reference is to Dr. Kerr Cross.

${ }^{26}$ British Central Africa Gazette, 1 October 1896. This reference is to Dr. Hearsey.

${ }^{27}$ List of medical practitioners, Nyasaland Government Gazette, 31 January 1910. This reference is to Dr. Barclay.

1s Blue Books, 1905-11. 
The department dealt with a series of health hazards in the early 1900s. Smallpox was a constant threat, and the demand for vaccination - the beginning of preventive measures-increased. ${ }^{29}$ The construction of the Chiromo to Limbe railway, through unhealthy country, was accompanied by much illness, and kept the doctor at Chiromo extremely busy. ${ }^{30}$ Outbreaks of beri-beri in 1904-1906 also took up much of the time of medical officers. ${ }^{31}$ In September 1905, plague attacked Chinde, the British Concession at the mouth of the Zambezi. Since Chinde was the port of entry to British Central Africa "it became a matter of vital interest to take immediate precautionary measures for the prevention and spread of the disease in British territory. All the available members of the Medical Department were accordingly stationed along a line extending from south to north ... to control the river and land routes into British Central Africa. A medical officer and nurse were despatched to Chinde; a medical officer, hospital assistant, and a trained dispensary assistant were stationed at Marka and Port Herald; and the medical officers of Chiromo and Blantyre were instructed to co-operate in the precautionary measures which were drafted and put into force". The measures included disinfecting and quarantining passengers entering the country and issuing them with health passports. ${ }^{32}$

Thus, by 1910 the medical department had established itself as the second largest department of government, although the staff numbers were not in themselves large. ${ }^{33}$ The staff establishment was stable and the funds allocated to the department, though small, were increasing annually so that the medical facilities were gently expanding and the staff were able to react promptly to health hazards as they occurred.

\section{II}

In the decade 1911 to 1921 increased activity was thrust upon the government. Unlike later periods when the government voluntarily expanded its medical work, at this time it reacted to pressing influences beyond its control: dangerous diseases and the First World War.

In the period 1901-1905 a sleeping sickness epidemic along the Lake Victoria Nyanza shore caused the death of one-quarter to one-third of a million people. ${ }^{34}$ Its possible spread was a constant threat to other countries, including Nyasaland. In 1907, a medical post was established in the extreme north of the country systematically to examine travellers from the infected region, ${ }^{35}$ and in 1908 two additional doctors were posted there. ${ }^{36}$ Further alarm occurred in 1909, when Dr. Hardy,

20 Protectorate Annual Report, 1905-6, p. 56.

${ }^{30}$ Ibid., 1906-7, pp. 47-48.

31 Ibid., 1904-5, p. 53; 1905-6, pp. 52-56; 1906-7, pp. 56-57.

22 Ibid., 1905-6, pp. 57-59.

as Blue Book, 1910. The three largest departments were: the District Administration with forty-two members, the Medical Department with seventeen, and the Public Works Department with fourteen. These figures are for senior established staff and exclude all other, more junior, posts.

"Lord Hailey, An African survey, London, Oxford University Press, 1945, 2nd ed., p. 1129;

Report of the East African Commission, 1925, London, H.M.S.O., 1926, Cmd. 2387, p. 56.

ss Protectorate Annual Report, 1906-7, p. 55.

${ }^{36}$ Gelfand, op. cit., note 2 above, p. 300. 


\section{Colin Baker}

then in charge of the only imported case, died of the disease. ${ }^{37}$ Thereafter rigorous efforts were made to restrict entry from the Congo and Tanganyika, but sleeping sickness did enter the country in 1910, and during the next few years developed dangerously even though the area affected was relatively small. ${ }^{38}$

Such were the fears of government that they took two important steps: the further increase of the medical staff by three doctors, ${ }^{39}$ and the employment of a Sleeping Sickness Commission of two more medical officers under Sir David Bruce. ${ }^{40}$ During 1908-1914 the government doctors and (over a shorter period) the commission, did much intensive and systematic work on sleeping sickness. By 1914, however, it was clear that, though endemic in the Dowa lakeshore area, there were no signs of the disease becoming epidemic. This, with the war-time need to redeploy medical staff, led to the commission's withdrawal in 1914.

The First World War seriously reduced the civilian work done by the medical department, and for most of the time seven of the eleven doctors were in the army.41 Quite apart from attending to war casualties and large detachments of soldiers living communally, the medical work involved in examining and looking after the 169,000 carriers was great. The carriers transported military equipment and stores, and their part in supplying the combatant units was vital. The care of the carriers' health was therefore crucial to military success. Even at the very end of the war there were seven major carrier hospitals, each in the charge of a doctor, with twenty orderlies and over 100 dressers, and accommodation for 1,400 carriers. There were also small hospitals along all carrier routes, each staffed by an orderly and dressers. ${ }^{42}$

No sooner had the war ended than the department was faced with two crises. During November and December 1918, more than fifty Europeans and an unknown number of Africans died of influenza, including ten military doctors and a nurse. ${ }^{43}$ In 1918 and 1919, an outbreak of bubonic plague called for close attention; over three million rats were killed, and the outbreak was confined to a relatively small area.4

Thus, during the decade 1911-1921, the government had, in effect, no alternative but to extend its medical work. Sleeping sickness and bubonic plague were scourges which could have decimated the country's population had urgent and careful measures not been taken. Similarly, the consequences of not fighting the German armies in East Africa could have been disastrous. The extension of medical work, however, was not fully reflected in the medical department budgets, since much war-time expenditure on medical work was not allocated to that department. Indeed, so far as the civil medical estimates were concerned, recurrent expenditure declined during the war and capital expenditure came to a complete standstill, whilst the expenditure per head of population dropped markedly, from 3.48 pence in 1911 to 1.86 pence in

37 Nyasaland Gazette, 31 March 1909.

38 Protectorate Annual Report, 1908-9, p. 16.

30 Blue Book, 1911; Legislative Council Proceedings, Seventh Session, 1911, p. 3.

4o Protectorate Annual Report, 1911-12, p. 18; Blue Book, 1912.

11 Blue Books, 1914-19.

12 Legislative Council Proceedings, Twentieth Session, 1918, p. 6.

as Nyasaland Gazette, 1918, pp. 378-379.

4 Protectorate Annual Report, 1920, pp. 6-7. 
1916. However, as we have seen, in fact, the amount of medical work increased substantially during, and because of, the war. The department's staff varied a good deal in numbers, the medical officers from fourteen (1912) to eight (1920) and nurses from seven (1911) to three (1918). The total strength of the department was the same in 1920 as it had been in 1910.4

\section{III}

Until the early 1920 s the medical service was designed primarily to care for government officials. This was clearly stated in Dr. Boyce's 1891 contract and remained the case for thirty years. Government hospitals and medical staff were located where government officials were stationed and not where the bulk of the population lived. This state of affairs prevailed during the First World War when the greatly expanded facilities were almost exclusively for military personnel and carriers. Thus, for the first time, hundreds of thousands of Nyasaland Africans had access to government medical services, and this was bound to lead to pressure-whether voiced or notto extend facilities after the war.

But the influence of the war was not sufficient in itself to induce what was, in essence, a considerable shift in policy, a shift towards social service as part of government's function, a move away from "law and order" administration towards development, a reorientation from focusing on the official element towards providing facilities for the African public. There were influences within Nyasaland such as the pressures of the missionaries who repeatedly complained about the inadequate medical facilities and pointed out that the Africans were getting little medical attention for the taxes they were paying. ${ }^{46}$ There is some evidence also that members of the administration shared these feelings and that expatriate planters were beginning to understand the economic advantages of a healthy population. ${ }^{47}$

There were also outside influences. Lugard's Dual mandate was published in 1922 and began to affect thinking on colonial administration. In 1923 the Colonial Secretary enunciated the paramountcy doctrine: "the interest of the African natives must be paramount . . .". Although this statement referred to Kenya, its implications for colonial policy were much wider, and indeed were formally stated to be of general application in the Passfield Memorandum of 1930. In 1927 the Governor of Nyasaland stated publicly that ". . . the welfare of the native population is the first care of Government ...".48 One must guard against overstating this shift in policy, particularly regarding medical services, because even as late as 1938, the Nyasaland Government confessed that much of the time of its qualified medical staff was devoted to the "care of the small and scattered European population": "the degree of attention which can be given to Africans is limited accordingly".49

us Blue Books, 1910-20.

" Legislative Council Proceedings, Twenty-second Session, 1920, p. 15; Twenty-fifth Session, 1925, pp. 8-9; Nyasaland Times, 17 March 1921.

" C. A. Cardew to the Chief Secretary, 17 March 1920, cited in R. I. Rotberg, The rise of Nationalism in Central Africa, Cambridge, Massachusetts, Harvard University Press, 1967, pp. 44-45; Report of the East African Commission, 1925, p. 53.

4 F. D. Lugard, The dual mandate in British Tropical Africa, London, Blackwood, 1922; Legislative Council Proceedings, Thirty-fourth Session, 1927, p. 6.

10 Protectorate Annual Report, 1938, p. 8. 


\section{Colin Baker}

The influence of the war in introducing large numbers of Africans to medical facilities, and the shift in policy towards African interests combined to bring about an expansion of medical services, particularly in the rural areas. This expansion was reflected in the growth of departmental staff, the amount of money spent on running the department, and the capital expenditure on medical works.

First, there were three important developments in staffing. The number of professional members (including medical officers, specialists, sub-assistant surgeons, matrons and nursing sisters) increased markedly and rose from twenty-eight in 1921 to forty-six in 1938.50 By the mid-1930s there was a medical officer or sub-assistant surgeon in charge of the hospitals at fifteen of the twenty district headquarters; at three others a hospital assistant looked after the dispensary; and the medical officers were now able to make monthly visits to the rural dispensaries. ${ }^{51}$ Second, the establishment and growth of a sanitation branch added a senior sanitation officer, two superintendents and nineteen inspectors to the department. ${ }^{52}$ To the efforts of the sanitation branch was added, after 1933, the enthusiasm of many of the newly created native authorities, some of whom appointed their own sanitation staff and promulgated sanitary rules. Third, there was the very substantial increase in the number of trained African employees staffing the rural hospitals and dispensaries built during the 1920s and 1930s, from forty-seven in 1921 to 487 in 1938.

Next, finances. At the end of the First World War, the Protectorate's funds were "in an eminently satisfactory condition" with a surplus of assets over liabilities of $£ 100,000$. A series of mishaps, however, caused this surplus entirely to disappear by 1922; the government secretariat building, destroyed by fire in 1919, had to be rebuilt; a famine of 1922 cost the government $£ 29,000$ in relief measures; a disastrous storm at Chinde so damaged goods and vessels as seriously to decrease customs revenue; and the many deaths from influenza so reduced the tax-paying population as to lower the hut tax revenue. Nonetheless, the money for development was found, initially largely through tax reforms, but later from British Colonial Development Fund sources. ${ }^{53}$

Recurrent medical expenditure, which had begun to rise during the second half of the war, rose annually, almost uninterruptedly, throughout the inter-war period, from $£ 20,000$ in 1921 to $£ 53,000$ in 1938 . Of this sum, approximately two-thirds throughout was devoted to salaries and wages, and only one-third to other items, although, wisely, expenditure on drugs and equipment increased sharply early in the period to supply the greatly increased number of new rural dispensaries, and thereafter remained at a relatively high level..$^{54}$ The proportion of recurrent expenditure devoted to medical services averaged eight per cent, being somewhat greater between 1924 and 1932, and somewhat lower at other times. The recurrent medical expenditure per head of population rose from 4 pence in 1921 to 7.7 pence in 1938 although these

so Blue Books, 1921-38.

${ }^{31}$ Dr. O. N. Ransford to C. A. Baker, 25 April 1973; Dr. W. T. C. Berry to C. A. Baker, 20

February 1973; Report on Native affairs, Nyasaland, 1933, p. 27.

62 Nyasaland Annual Estimates, 1938, pp. 34-35.

s8 Legislative Council Proceedings, Twenty-first Session, 1919, pp. 6, 7; Twenty-second session. 1920, p. 4; Twenty-fifth Session, 1922, p. 2; Twenty-seventh Session, 1923, pp. 4, 10.

54 Nyasaland Annual Estimates, 1921-38. 


\section{The government medical service in Malawi, 1891-1974}

figures did not compare favourably with those of Tanganyika where the increase was from 2.7 pence to 14 pence, and Kenya, from 6.9 pence to 18 pence. ${ }^{55}$

Capital expenditure on medical buildings came from internally raised Public Works Department votes and (between 1931 and 1936) from Colonial Development Fund grants. Between 1921 and 1938 this expenditure totalled 183,500 ; two-thirds of this, however, was expended in 1931 and 1932 when $£ 55,000$ of Colonial Development Fund money was spent on much-needed buildings such as twelve district hospitals and seven doctors' houses, whilst more than twenty new rural dispensaries were added to the seventy built with government funds in 1922. Such was the impact of the Colonial Development Fund grants that even Lord Hailey was under the impression that all ninety-three rural dispensaries in 1940 had been built solely with funds from that source. ${ }^{56}$

Thus, between the two world wars medical facilities expanded significantly and the number of people, particularly in the rural areas near the new dispensaries and hospitals, who had access to medical treatment, increased considerably. Indeed, the number of cases dealt with rose from 19,000 in 1921 to 729,000 in 1937; that is, from one case for every 62 members of the population to one for every 2.2 .

Although the greatest emphasis continued to be placed on curative medicine, significant additional steps were also taken in prevention. A government doctor was seconded to the staff of the resident engineer in charge of constructing the Lower Zambezi bridge and spent much time inspecting the hospital and labour camps there in 1934. Shortly after this the director of medical services sent his medical officers for a week or two each year to carry out village surveys, and in 1937 the department commented on its new work in inspecting school-children and checking labour conditions on private estates. ${ }^{57}$ In the same year, a system of medical camps was introduced in which medical staff went into rural areas to give practical demonstrations and to lecture on sanitation. ${ }^{58}$

Data are available for 1936, which assist in comparing Nyasaland medical services with those in other British African countries. Nyasaland spent a rather smaller percentage (seven per cent) of its annual recurrent budget on medical services than the average (nine per cent), but had slightly more beds available to Africans in its government hospitals $(3.3$ per 1,000$)$ than the average $(2.9$ per 1,000$)$.

Thus, the inter-war period was one of considerable development of the government medical service. With a policy reorientation towards emphasizing African interests, the staff of the department expanded, particularly the number of trained African employees; the recurrent expenditure on medical facilities more than doubled; substantial capital sums were spent on building rural hospitals and dispensaries; and the volume of work accomplished-both curative and preventive-particularly in the rural areas, expanded appreciably.

\footnotetext{
ss Calculated from data given in Ann Beck, $A$ history of the British medical administration of East Africa, 1900-1950, Cambridge, Mass., Harvard University Press, 1970, appendix, pp. 215-224.

s8 Blue Books, 1931-32; Lord Hailey, Confidential report on native administration and political development in British Tropical Africa, 1940-42, London, H.M.S.O., p. 267.

${ }^{67}$ Dr. P. J. Bourke to C. A. Baker, 18 March 1973; Protectorate Annual Report, 1937, p. 9.

ss Dr. W. T. C. Berry to C. A. Baker, 20 February 1975 and 26 April 1973; Annual report of the Provincial Commissioners, Nyasaland, Southern Province, 1938, p. 14.
} 


\section{Colin Baker}

\section{IV}

Relatively little information is available for the Second World War, but two features are known: recurrent expenditure continued to increase, and a considerable proportion of civilian medical staff moved to military work.

In 1941 the British Government gave instructions and advice as to the war-time financial policy of its overseas territories, including a "request . . . to improve the standard of living of the poorer classes". ${ }^{59}$ Responding to this request, Nyasaland increased its medical vote from $£ 52,000$ in 1939 to $£ 73,000$ in 1945 , and from seven per cent of total recurrent expenditure in 1939 to fourteen per cent in 1942 although it fell back to eleven per cent in 1945.

By July 1940, eight medical officers were seconded for military service. A nursing sister was seconded in 1940 and another in 1943, so that the department fell well below its normal staffing level. ${ }^{80}$ However, at least one mission doctor was made available to government, ${ }^{61}$ and it is likely that a number of married nursing sisters resumed work. The Zomba hospital also stepped up its training of Medical Orderlies and Dressers for the military forces. ${ }^{62}$

\section{V}

In the eight years between the end of the war and 1954 when the medical department was placed under the Federal Government of Rhodesia and Nyasaland, the medical service expanded at an unprecedented rate. Again, the exposure of large numbers of Nyasalanders, particularly soldiers, to free government medical services during the war, together with the greater egalitarian trend in general world politics (not least in the election of the Labour Party to power in Great Britain) contributed to this expansion. There was a marked upswing in government revenue which enabled larger sums to be devoted to medical work, although the proportion of total annual recurrent expenditure returned to the pre-war seven per cent level.

During this period recurrent medical expenditure almost trebled, rising from $£ 90,000$ to $£ 250,000$, and for the first time the proportion of this expenditure devoted to non-salary "other charges"-including particularly drugs and equipment-rose above and remained above forty per cent. Similarly, per capita expenditure trebled, from 9.7 pence in 1946 to 23.8 pence in 1953.

Capital expenditure was also impressive when compared with general pre-war levels, and within a few years of the war ending it matched or greatly exceeded the heyday period of Colonial Development Fund grants in 1931-1932. These funds were devoted to building a mental hospital, medical training school, leprosy settlement and hospital steam laundry, and to building or improving other hospitals and dispensaries. ${ }^{63}$ Four dispensaries were extended to form Rural Health Units staffed by a health assistant, medical aide, sanitary assistant and midwife. ${ }^{64}$ Plans and contract documents were also drawn up for a $£ 750,000$, eight-hundred-bed hospital in Blantyre,

30 Legislative Council Proceedings, Fifty-seventh Session, First Meeting, 1941, p. 15.

io Nyasaland Gazette, 1939-45, passim.

11 Legislative Council Proceedings, Fifty-sixth Session, 1940, p. 8.

os Ibid.

ca Nyasaland Annual Estimates, 1946-1953; Protectorate Annual Reports 1947-53.

o4 Protectorate Annual Report, 1952, p. 88; 1953, p. 96. 
designed to become "the main curative and clinical research centre . . . as well as providing facilities for the training of medical assistants and general nurses". ${ }^{65}$ The excution of these plans fell to the Federal Government after 1953.

Continued training of hospital assistants, medical aides, midwives and nurses produced a small but steady supply of auxiliary personnel, although the total number increased very little. But it was at the senior professional level that the most important staff additions took place: five medical officers, eight nursing sisters, three health inspectors, three specialists and an assistant director of medical services. ${ }^{66}$

Staff improvements enabled the doctors not only to deal more satisfactorily with their hospital work and with emergencies such as smallpox outbreaks and famine relief, but also to adopt a more positive approach to rural health education. They introduced, encouraged and supervised regular visits by dispensary staff to rural areas to teach and persuade villagers to adopt better sanitary and hygiene measures. ${ }^{67}$

In the early 1950s an air of progress existed; experiments were conducted in the use of insecticides on a large scale, and in bilharzia control by drainage; training of African staff was stepped up with the opening of a second training school, the insistence upon higher entry qualifications and the introduction of refresher courses for auxiliary staff; health surveys were conducted; a massive smallpox vaccination campaign was introduced, designed to cover the whole country every three years; a leprosy settlement was established and a detailed leprosy survey was embarked upon. ${ }^{88}$ Funds and staff-although never in the quantities required-were sufficient to continue this development. In 1954, however, the medical department became a federal responsibility, no longer under the direct control of the government and people of Nyasaland.

\section{VI}

African politicians, much opposed to the Federation, lost no opportunity to condemn it, and medical matters came in for a good deal of criticism; their fear of a deterioration in medical services was great and vociferously expressed. It was difficult to raise the matter in the Nyasaland legislature, and it seemed to the African members - with justification - that if they wished to raise federal matters (in order to criticize) they were ruled out of order, whereas if others so wished (in order to praise) they were allowed to do so. ${ }^{69}$ Nonetheless, they occasionally succeeded in voicing their views that the Federal Government was providing grossly inadequate facilities, the African staff were discriminated against, African politicians were refused treatment, important hospitals no longer had medical specialists, and not only were Africans opposed to working for the federal government, but many Europeans shared their views. ${ }^{70}$

es Ibid., 1953, p. 96.

o6 Ibid., 1953, pp. 94-95; Nyasaland Annual Estimates, 1946-53.

"7 Protectorate Annual Report, 1952, p. 84.

${ }^{68}$ Ibid., 1948, p. 35; 1949, p. 44; 1950, p. 54; 1951, pp. 61-64; 1952, pp. 83-89; 1953, pp. 89-97.

- For example, Legislative Council Proceedings, Seventy-second Session, First -Meeting, 1957, pp. 72, 80, 82, 104, 112; Second Meeting, 1958, pp. 69 ff; Third Meeting, 1958, pp. $5 \mathrm{ff}$; Seventy-third Session, First Meeting, 1958, pp. 36, 171.

${ }^{70}$ Ibid., Seventy-second Session, Second Meeting, 1958, pp. 73-74, 77, 79, 88; Seventy-third Session, Second Meeting, 1958, p. 209. 


\section{Colin Baker}

Medical expenditure in Nyasaland did, in fact, increase considerably during the federal decade. Recurrent expenditure rose from $£ 248,500$ in 1953 to $£ 1,052,300$ in 1962. In 1953 the Nyasaland government devoted seven per cent of its recurrent expenditure to medical services, whereas in 1962 the Federal Government's expenditure on these services in Nyasaland was equivalent to twelve per cent of Nyasaland's total recurrent expenditure. ${ }^{71}$ In reply to the objection that what was important was not how much money was spent but on what it was spent, the Nyasaland government claimed that the expenditure in Nyasaland on drugs and equipment alone in 1958 was higher than the total expenditure on all medical services in $1952 .{ }^{72}$ The number of cases dealt with in government health centres rose from 3,600,000 in 1954 to $7,900,000$ in 1962.

Staffing contrasted unfavourably with the satisfactory position of finance and the number of cases dealt with. Nyasaland medical staff were seconded to the Federal Government until 1959 by which time they were required to transfer to the Federal Service or to resign. The Nyasaland staff numbered 1,241 in $1953^{73}$ but by the end of June 1958, this number had dropped over fifty per cent to $599 .{ }^{74}$ During this same period, of the forty professional medical staff who left Nyasaland government employment, only twelve (thirty per cent) transferred to the federal service; and of the thirty-four other senior members of staff only three (nine per cent) so transferred..$^{75}$ Although the number of government medical officers in Nyasaland increased from twenty-five in 1952 to thirty-seven in 1958 , only seven were seconded from the Nyasaland service. ${ }^{76}$ Only forty-four per cent of the African staff transferred to the federal service. ${ }^{77}$

Nyasalanders, unlike expatriates, had little alternative to finding employment locally, and few could afford to retire permanently. It was claimed by the Nyasaland government that they had "a free choice. ... There is no compulsion at all ... no question of them being discharged in the true sense of that term. They will be offered reabsorption in a comparable position in the Territorial service...". This reassurance, however, was dashed almost in the same breath: "It is unlikely that it will be possible to reabsorb any large numbers of them. Moreover, it would in any event not be possible to offer comparable employment to ... officers such as Medical Aides". ${ }^{78}$ A last-minute attempt in the legislature to avoid resignation or transfer, by retaining them in territorial government service, failed. ${ }^{79}$ Despite the personal sacrifices which resignation involved, there was a massive reluctance to transfer to the federal service, and this reluctance manifested itself in a determined form before July 1958.

The Federation was formally terminated on 31 December 1963, but it was agreed to transfer responsibilities to the territorial governments before that date, if adequate

71 Treasury Document No. 5, 1966, p. 28.

72 Legislative Council Proceedings, Seventy-second Session, Third Meeting, 1958, pp. 7, 21.

${ }^{78}$ Nyasaland Annual Estimates, 1953, pp. 61-66.

"Ibid., 1958/9, pp. 280-281.

${ }^{75}$ Nyasaland Government Staff Lists, 1953-58.

${ }^{76}$ Legislative Council Proceedings, Seventy-second Session, Second Meeting, 1958, p. 84; Nyasaland Annual Estimates, 1958/9, p. 280.

77 Ibid., Seventy-third Session, First Meeting, 1958, p. 156.

78 Ibid.

79 Ibid., pp. 155ff. 
staff could be employed. By July 1963, a director of medical services had been engaged, but the number of medical officers had dropped to fourteen, ${ }^{80}$ and there was an uncompensated outflow of medical stores from Nyasaland to Rhodesia totalling over $£ 11,000$ between July 1962 , and July $1963 .{ }^{81}$ This could have done little to enhance confidence in the good faith of the Federal Government, and it still rankled several years later. ${ }^{82}$

By November 1963, the Ministry of Health was handed back to the Nyasaland government, which had secured the services of sufficient staff to make a start on running the health services. ${ }^{83}$ By 1 January 1964, the ministry was well up to establishment, over 500 trained junior members of staff transferring from the Federal Government. ${ }^{84}$ Later in 1964, forty-four officers who had resigned in 1959 rather than join the Federal Service, were reinstated. ${ }^{85}$ During 1964 a number of established senior posts were held in abeyance, possibly because the government was initially uncertain that it could afford all the posts which it wished to establish. ${ }^{88} \mathrm{~A}$ year later, however, confidence had returned and parliamentary sanction was granted for new professional staff. $^{87}$

\section{VII}

Since independence, Malawi has continued to expand its medical services with substantial increases both in the staff and in expenditure.

The staff of the Ministry of Health increased by fifty per cent between 1964 and 1974, the most important growth being among the specialists, medical officers, nurses and clinical officers. 88

In colonial times, the law relating to medical registration was highly biased in favour of British qualifications. ${ }^{89}$ Thus, the number of medical practitioners who did not hold such a qualification was very small indeed, although after the Second World War it increased slightly. ${ }^{\circ 0}$ The President of Malawi, Dr. H. K. Banda, has frequently related how, despite his medical qualifications from the U.S.A., he had to obtain a British qualification to be registrable in his own country. ${ }^{91}$ Since independence, however, the country has been much less restrictive and government doctors have been drawn from some twenty different countries, although the majority first qualified in either the United Kingdom or Holland.

The number of Malawian doctors rose from three in 1964 to twelve in 1972. An

${ }^{20}$ Ibid., Seventy-sixth Session, Ninth Meeting, 1963, pp. 847-848.

81 Ibid., p. 919.

i2 Proceedings of Parliament, Fourth Session, Third Meeting, 1966, pp. 94, 216-217.

os Legislative Council Proceedings, Seventy-sixth Session, Tenth Meeting, 1963, pp. 918-920.

st Ibid., Nyasaland Gazette, 1964, pp. 185-187, 195-196, 203-204.

${ }^{85}$ National Assembly Proceedings, First Session, First Meeting, 1964, p. 102; Third Meeting, 1964, p. 218.

86 Legislative Council Proceedings, Seventy-sixth Session, Eleventh Meeting, 1964, p. 1162.

${ }^{87}$ National Assembly Proceedings, Third Session, First Meeting, 1965, p. 172.

${ }^{88}$ Annual Estimates, 1964, 1971; Staff Lists, 1965, 1971.

80 The Registration of Medical Practitioners Ordinance, No. 9 of 1906.

${ }^{20}$ Annual list of registered medical practitioners, Nyasaland Gazette, 1946-53.

01 Proceedings of Parliament, Second Session, Fifth Meeting, 1965, p. 693; 


\section{Colin Baker}

interesting passage touching upon the employment of Malawian doctors appeared in the Legislative Council Proceedings of 1941: "I would like to move the deletion of the provision of $£ 315 \ldots$ it was provided for the services of an African doctor who has been training in England and has passed his medical examinations, but it has since been found that he is not the right sort of man for Government employment and it has been agreed not to employ him." ${ }^{22}$ Dr. H. K. Banda qualified in Britain in $1941 .{ }^{93} \mathrm{Had}$ he then returned to his home country as a government officer, the course of history in Central Africa might have been different. ${ }^{94}$

Annual recurrent expenditure has increased by ninety-three per cent since independence, from $£ 987,000$ in 1964 to $£ 1,906,000$ in 1974. To deal with the point raised in Federal times that it is not how much money but what it is spent on that matters, expenditure on medical stores and equipment rose from $£ 219,000$ in 1964 to $£ 505,000$ in 1974. In 1964 eighty-eight per cent of all recurrent expenditure was devoted to curative services and six per cent each to administration and preventive services. By 1974 the curative proportion had dropped to eighty per cent, whilst administration had risen to twelve per cent, and preventive services to eight per cent. ${ }^{95}$ There is still, therefore, a very heavy concentration on curative medicine.

\section{VIII}

In these concluding paragraphs we shall look at the developments which have taken place over the past eighty years, by briefly reviewing finance and staffing, and then by examining medical policy.

Save for a drop during the First World War, there has been a continuous rise in the amount of money spent each year on running the government medical services. From a very small sum, $£ 250$, barely sufficient to cover the salary of the single medical officer in 1891, it has risen to $£ 1,906,000$ in 1974 . On the whole, expenditure on medical services has kept pace with the general increase in total government expenditure, and has remained at seven per cent to eight per cent of total expenditure over long periods. Unlike the fairly steady increase in recurrent finance, capital expenditure has varied a good deal, periods of exceptional growth alternating with periods of relative inactivity.

The annual per capita expenditure on medical services has risen steadily from about one penny at the turn of the century to about ninety-four pence today. ${ }^{96}$

Turning now to the staff: by 1901 a distinct and comparatively well-staffed department existed, with a principal medical officer in charge of eight doctors and seven nurses. Over the following five decades the staff increased to 1,251 , and although it is difficult to know precisely how well the Federal Ministry of Health staffed Nyasaland, it is clear that the staff numbers were substantially lower at the end of the

${ }^{92}$ Legislative Council Proceedings, Fifty-seventh Session, First Meeting, 1941, p. 4.

os List of registered medical practitioners, Malawi Gazette, 1969, p. 52.

94 For a biography of Dr. Banda, see Philip Short, Banda, London, Routledge \& Kegan Paul, 1974.

${ }^{95}$ Annual Estimates, 1964-1973/4; Malawi: an official handbook, London, Blantyre, 1968, p. 87;

1969, p. 71; 1970, pp. 70-71; Development Programme, 1970-72/73, vol. I, table A.

${ }^{96}$ Pence here and elsewhere in this article are at the rate of 240 to the pound sterling. 
Federal era than they had been at the beginning. Today there are over 1,750 employees in the ministry.

The number of specialists has increased over the years. The first specialist was a medical entomologist employed in 1914. In 1932, a second specialist, a pathologist, was appointed. By the beginning of the Second World War, a dental surgeon and a pharmacist had joined the service, and when the Federal Government assumed responsibility there were a surgical specialist, a medical specialist, a pathologist, a radiographer, two dental surgeons and two pharmacists. When the territorial government first resumed responsibility, the number of specialists appointed (seventeen) was only slightly fewer than the number of general medical officers (nineteen). Today there are thirty-one specialists and forty-three other medical officers.

Developments in medical policy are difficult to trace because, particularly in the past, specific policy statements were rarely made. One is often obliged, therefore, to discover the policy by inference from the way in which the services were administered, and from indirect sources.

In the early 1890 s the aim was to provide medical facilities for government officials. It is probable that Johnston was very much concerned with his personal health, but also with that of his officials: "He is a funny little man and worries a great deal. If anyone is ill he is always in a great state of mind". ${ }^{97}$ It is clear from Dr. Poole's letters that he treated people of all races-African, Indian and European-and that his work was not confined to government employees. He built a hospital and a dispensary in Zomba in 1895, and the former, at least, was for Africans. ${ }^{98}$ The early policy, then, probably was that government medical officers were engaged primarily to treat government employees, of whatever race, but also to deal with any nonofficials who happened to be in the vicinity.

By the early 1900 s the government had begun to look upon itself as being responsible for a national medical service. The service was not necessarily free, it certainly was not universal, it was severely limited in scope and it relied heavily upon the complementary services of Mission doctors and nurses. Nonetheless, a medical department already existed and its annual reports were comprehensive, detailed, and covered all sections of the population.

The overwhelming emphasis was on curative medicine but already the beginnings of prevention were appearing: although public health activities were largely confined to the town councils, the government medical officers were advisers to these councils and usually the collector was chairman.99 Some rural public health work was also undertaken in areas where beri-beri occurred, ${ }^{100}$ and a system of inspection of government institutions, specifically including hospitals and dispensaries was introduced. ${ }^{101}$ The 1908 Vaccination Ordinance rendered everyone in the Protectorate liable compulsorily to be vaccinated, and one of the purposes of the 1912 District Administration (Native) Ordinance was to improve the public health of the rural areas. To these preventive measures must be added the very considerable amount of work done in

"7 Gelfand, op. cit., note 3 above, p. 53.

98 Ibid., pp. 23-27, 31.

oo Protectorate Annual Report, 1904-5, p. 55.

${ }^{100}$ Ibid., 1905-6, p. 56.

101 Ibid., 1905-6, p. 41. 


\section{Colin Baker}

combating sleeping sickness. It appears, therefore, that in the decade before the First World War a good deal of work in preventive medicine was done, but it was greatly exceeded by curative work.

After the First World War, curative activities were expanded by the building of district hospitals and ninety rural dispensaries. Again, despite advances in preventive coverage by the creation of a Sanitation Branch in 1924, and the realization that over one-third of the diseases suffered by the African population were already preventable, ${ }^{102}$ the emphasis continued overwhelmingly to be on curative medicine. The government, however, was ever anxious to increase its preventive activities and used the 1933 Native Authority Ordinance to place responsibility for rural sanitation in the hands of native authorities.

By the end of the inter-war period, then, it was part of government's policy that preventive medicine should, to a large extent, be in the hands of local authorities, partly for philosophical, partly for financial and administrative, reasons: “. . . the policy of the Government is based on the assumption that a healthy environment is essential for the intellectual and material progress of a people"; 103 "since a highly trained and expensive Public Health Department is impracticable, the efforts to improve sanitation and hygiene in the bush should be organized from below through the Native Authorities". ${ }^{104}$ Some influential views, however, went further. The director of medical services was of the view-and in this he was supported by no less an authority than Lord Hailey - that "the native authorities [should] take over responsibilitity for the [rural] dispensaries and their staff", ${ }^{105}$ that is, that a very large portion of all rural medicine, curative as well as preventive, should be transferred to local authority control. The director may have had administrative and financial reasons, but Lord Hailey's support was based on "pursuing the political aim of establishing the native authorities as local government bodies." 108

In 1948 the British government held a conference attended by delegates from the legislative councils of the British Africa territories. ${ }^{107}$ They discussed medical policy and were urged by the British government to place emphasis on preventive medicine: "the people should become health- and not hospital-conscious", and should "think in terms of real health, not the patching-up of sick people". ${ }^{108}$ Although the Nyasaland delegation accepted the principles and logic of the arguments which preferred preventive to curative medicine, they raised doubts as to the practical and financial implications of swinging policy too far in favour of prevention: "curative and prevention are of the same importance and neither should take advantage over the other"; "the medical staff . . . is so fully occupied with the curative that the preventive side suffers and also the finances available are inadequate". ${ }^{109}$

102 Ibid., 1927, p. 17.

103 Memorandum on native policy in Nyasaland, Zomba, 1939, p. 13.

104 Report of the commission appointed to enquire into the financial position and further development of Nyasaland, London, H.M.S.O., 1938, p. 216.

${ }^{105}$ Hailey, op. cit., note 56 above, p. 268.

108 Ibid., p. 268.

107 African Conference, 1948, African No. 1175 (Conference Papers) and No. 1176 (Minutes of Conference Sessions).

${ }^{108}$ Ibid., No. 1175, p. 50.

109 Ibid., No. 1176, p. 62. 


\section{The government medical service in Malawi, 1891-1974}

Possibly the Colonial Office Advisers were disturbed at a tendency, occurring at least in Nyasaland, for the proportion of medical expenditure on prevention to fall. In Nyasaland, in 1928, 13.9 per cent had been devoted to preventive medicine; in $1938,10.8$ per cent; and in 1948, only 5.6 per cent. By 1953 , possibly as a result of British Government pressure, the proportion had risen slightly, to 7.6 per cent. ${ }^{110}$ In any event, it is clear that despite advances in preventive coverage, the overwhelming emphasis continued to be on curative measures.

A clear policy statement is contained in the Development Programme, 1970$1972 / 73$, which categorically refuses to divert funds from curative to preventive services. "With an ever-growing population and an ever-increasing pressure on available hospitals and health units, there can be no question of any switching of funds from curative to preventive functions". 111 This does not mean, however, that the emphasis will not change so as to favour prevention rather more than formerly, but only that there will be no diminution of curative services in favour of preventive.

Thus, it is likely that expenditure on preventive medicine will increase at a faster rate than that on curative medicine, and this implies a movement of resources towards the rural areas, a reinforcement-in terms both of facilities and of personnel-of the rural dispensaries and health units, and a strengthening of staff engaged in rural health education.

These recent developments do not, in fact, indicate a policy break from the past but only that a solution has been expounded which, whilst not allowing a diminution of curative services, permits of a planned expansion of preventive measures. All the important policy threads of the past are still to be found in the current fabric: an expanding government medical service which caters for both government officials and increasingly for the general public; consequently a gentle increase in the number of specialists and general medical officers (although both these expansions are likely to be very slow over the next few years); a continuation of the improvement of medical installations in the rural areas; and a continuing development of preventive measures, particularly in the rural areas where the great bulk of the population resides-but not at the cost of curative services.

In looking back over the past eight decades, one may legitimately criticize the government, particularly in colonial times, for not having developed the medical service as fully as it ought and for not having devoted sufficient funds to medical work. But in doing so, one must place this criticism against the fact that the government provided a public health service-no matter how defective-long before more developed nations broke with the tradition of leaving medical facilities to private enterprise. British Central Africa had some form of public health service half a century before the National Health Service was created in Britain. Even today some of the leading nations of the world still leave the matter to private enterprise.

${ }_{110}$ Annual Estimates, 1928, 1938, 1948, 1953.

111 Development Programme, 1970-72/73, Zomba, Government Printer, vol. I, Policy Statement of the Ministry of Health, p. 1. 